\title{
Changes in morphometric characteristics of nematode communities during a spring phytoplankton bloom deposition
}

\author{
Jan Vanaverbeke ${ }^{1, *}$, Karline Soetaert $^{2}$, Magda Vincx $^{1}$ \\ ${ }^{1}$ Ghent University, Biology Department, Marine Biology Section, Krijgslaan 281/S8, 9000 Gent, Belgium \\ ${ }^{2}$ Netherlands Institute of Ecology, Centre for Estuarine and Marine Ecology, PB140, 4400 AC Yerseke, The Netherlands
}

\begin{abstract}
Nematode body size was investigated in terms of body length, width and length/width (L/W) ratios, before, during and shortly after a spring phytoplankton bloom deposition in a station in the southern North Sea (20 m depth). Sediments consisted of medium sand (median grain size: $333 \mu \mathrm{m}$ ) and were devoid of mud. Redox values in the upper $6 \mathrm{~cm}$ of the sediment were positive $(>100 \mathrm{mV})$ throughout the sampling period. During the peak of the spring phytoplankton bloom in May 1999, several small-sized species (adult length $<700 \mu \mathrm{m}$ ) emerged. Most prominent was the appearance of a 'stout' nematode assemblage characterised by low L/W ratios. Most of these small nematode species were virtually absent before the peak blooming, and they decreased in abundance shortly after deposition of phytoplankton to the seafloor. This indicates the opportunistic behaviour of these nematodes, which is consistent with their small length, enabling them to reach adulthood rapidly. The net rate of increase of the stout nematodes during the bloom was estimated as $6.4 \% \mathrm{~d}^{-1}$. This is much larger than the estimated net rate of $1.5 \% \mathrm{~d}^{-1}$ for the total nematode community. The species composition of the stout nematode assemblage differed from similar stout assemblages described for continental slope and deep-sea areas. In the southern North Sea, Epsilonematidae were dominant while members of the Desmoscolecidae were prominent in offshore deeper areas. Possibly these differences reflect the relatively strong hydrodynamic forces at the North Sea site. In contrast with their short temporal appearance at our coastal North Sea site, stout nematodes seem to be a consistent member of deep-sea nematode communities. We hypothesise that this is caused by the quality of organic matter reaching the seafloor, together with differences in sedimentology and temperature, influencing the duration of the presence of suitable food items for these nematodes.
\end{abstract}

KEY WORDS: Nematodes $\cdot$ Benthic-pelagic coupling $\cdot$ Size $\cdot$ Shape

Resale or republication not permitted without written consent of the publisher

\section{INTRODUCTION}

Research on the response of benthic communities to food-enrichment mostly focuses on changes in species composition and/or biomass patterns (Graf 1992 and references therein). A combined approach, whereby species data are linked with the corresponding bodysize parameters, has rarely been published. This is surprising, since body size influences many aspects of animal life such as life history, physiology, energy requirements, biotic and abiotic interactions (Peters
1983, Schwinghamer 1983, Calder 1984). The optimal size of an organism can be linked with its food input (Sebens 1987, Rex \& Etter 1998)-especially in the case of nematodes, in which morphology (expressed as width/length ratios) reflects the feeding mode of the organisms (Tita et al. 1999). Therefore, changes in the size structure of a community are expected during a food deposition event.

Nematodes are among the most abundant metazoan organisms in marine sediments and, as their length and width are easily measured using non-destructive 
methods (Soetaert et al. 2002), they are especially suited for analysing body-size distributions. Moreover, the ratio of the nematodes' length to the maximal width (L/W) offers a quantitative measure of their shape. While most nematodes have a typical snakelike body, some species are conspicuously plumper. Ratsimbazafy et al. (1994) were the first to report the existence of these 2 different nematode morphotypes in fine sandy sediments (median grain size 130 to $160 \mu \mathrm{m})$ of the North Sea. Soetaert et al. (2002) analysed nematode morphology from various continental slope areas around the world and confirmed the existence of both morphotypes. As both groups included members of distantly related taxa, they concluded that these groups arose as an adaptation to evolutionary conflicting constraints. Based on indirect evidence, they hypothesised that the short, stout type could persist due to its more rapid development compared to longer nematodes, whereas the presence of 'armour' and its thickness were effective against predation pressure. However, the concomitant lowered mobility and reduced capacity to withstand anoxic conditions obliged these stout organisms to live in the well-oxygenated surficial layers of the sediment (Soetaert et al. 2002).

Our study investigates the morphometry of nematode communities as triggered by a spring-bloom phytoplanktonic deposition in a well-oxygenated North Sea sampling station. We describe the changes in length, width and L/W ratios as a result of the changing food availability in the sediment. We investigate whether 2 morphotypes can be discerned and how both respond to a pulsed food supply.

\section{MATERIALS AND METHODS}

Study site, sampling and treatment of samples. Samples were obtained from an open-sea site, Stn 330 (51 $26.0^{\prime} \mathrm{N}, 02^{\circ} 48.5^{\prime} \mathrm{E}$, depth $20 \mathrm{~m}$ ) (Fig. 1) on the Belgian Continental Shelf (Southern Bight of the North Sea). Sampling was performed weekly from March to July 1999. Nematode species were identified at monthly intervals (9 March, 27 April, 12 May, 28 June and 12 July 1999). Morphometric analysis of the communities was performed on the samples from March, May and July, i.e. before, during and after the spring phytoplankton bloom.

Sampling took place aboard the RVs 'Belgica', 'Zeehond' and 'Oostende XI' using a modified Reineck boxcorer. The boxcorer was deployed 3 times on each sampling occasion. From each boxcorer, 1 perspex core $\left(10 \mathrm{~cm}^{2}\right)$ was used for faunal analysis down to $10 \mathrm{~cm}$ sediment depth. Additional cores were used for the analysis of sediment characteris- tics, pigment concentrations and nutrient profiles ( $\mathrm{J}$. Vanaverbeke \& M. Steyaert unpubl.). In July, only 2 cores were available for faunal analysis. Sediments were sliced vertically; the upper $2 \mathrm{~cm}$ in $5 \mathrm{~mm}$ intervals, the deeper layers into $1 \mathrm{~cm}$ intervals. A hot $\left(70^{\circ} \mathrm{C}\right)$, neutral formaldehyde tap-water solution was used for fixation. Metazoans passing through a $1 \mathrm{~mm}$ sieve and retained by a $38 \mu \mathrm{m}$ sieve were extracted from the sediment by centrifugation with Ludox (Heip et al. 1985). We picked out 120 nematodes randomly from each slice and mounted them on Cobb slides for identification and measurement of length and maximal width. When less than 120 individuals were present, all nematodes were picked out. Measurements were performed using an image-analyser (Quantimet 500+). For each individual, age, gender and presence of eggs (in adult females) was recorded. Sediments were analysed using a Coulter LS100 particle size analyser. The redox potential $(\mathrm{mV})$ of the sediment column was recorded with an $\mathrm{mV}$ meter in intact cores at each sampling event to a maximum sediment depth of 5 to $6 \mathrm{~cm}$.

Chlorophyll a ( $\mathrm{chl} \mathrm{a}$ ) values at the sea surface were obtained from Rousseau (2000). The supernatant water in the Reineck boxcorer was carefully siphoned off, and $0.5 \mathrm{l}$ was filtered onto Whatman GF/C filters. Filters were stored in a freezer until processing. Chl a values were obtained by HPLC (Gilson) using the slightly modified method of Mantoura \& Llewellyn (1983).

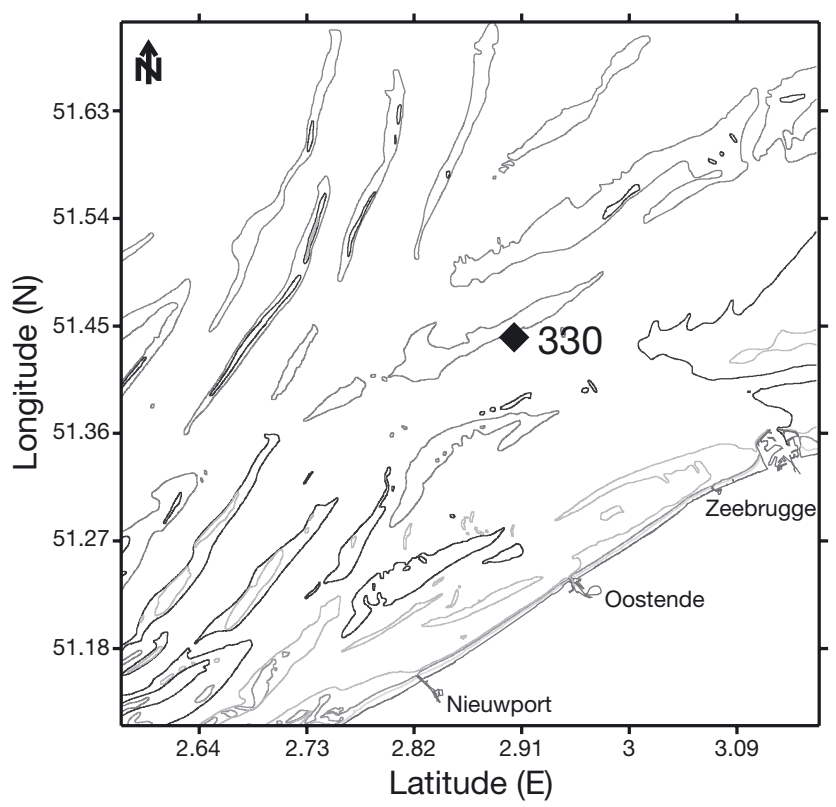

Fig. 1. Map of Belgian Continental Shelf, showing location of Sampling Stn 330 (depth 20 m) 
RESULTS

\section{Study site}

Sediments at the sampling station could be classified as medium sand (median grain size ranging from $329 \mu \mathrm{m}$ in May to $361 \mu \mathrm{m}$ in June) (Buchanan 1984), devoid of mud. Chl a values in the water column (Fig. 2) reached highest values on 29 April and 5 May, reflecting the peak phytoplankton bloom. The pattern at the surface was closely followed by that of the pigment concentrations in the supernatant water, indicating sedimentation of phytoplankton from the end of April. At the date of the first sampling, high chl a values in the supernatant water were observed. Redox values remained positive (>100 mV) during the whole sampling period at all sediment depths (Vanaverbeke 2003).

\section{Morphological diversity of the nematode communities}

All measurements (all replicates and sediment slices) per month were pooled before analysing the morphometry of the nematode communities. In March, May and July, respectively 491, 1441 and 528 nematodes were measured.

At the onset of the bloom in March, nearly all nematodes $(>98 \%)$ were of the slender type (Fig. 3), with $\mathrm{L} / \mathrm{W}$ ratios well over 15 and peaked at L/W of 32 . One species, Dichromadora cucullata, dominated the community $(18 \%)$. The peak in adult size at 800 to $900 \mu \mathrm{m}$ (Fig. 4) is due to this species; 4 other, larger, nematode species (Neochromadora angelica, N. munita, Prochromadorella ditlevseni, Pomponema multipapillatum) made up another $12 \%$ of the total community.

Shortly after the bloom deposition, dominance clearly shifted towards much smaller species, adult size 300 to $400 \mu \mathrm{m}$ (mainly Epsilonema pustulatum, Metepsilonema comptum, Mannunema annulatum), and 600 to $700 \mu \mathrm{m}$ long (several Rhynchonema species, Richtersia inaequalis, Daptonema nanum, Tricoma sp.) individuals (Fig. 4). Together, these small species comprised $38 \%$ of the community. Codominant during this period was a somewhat bigger species, Microlaimus marinus $(900 \mu \mathrm{m})$. In the length-width scatterplots (Fig. 3), a more diverse assortment of shapes could be discerned during this period: although the slender type of nematodes still comprised the bulk of the assemblage, the stout nematodes were also prominent $(21.5 \%)$. These latter nematodes, with relatively low length and high width values are easily identifiable in the L/W fre- quency plot by the first peak at L/W ratios of 9 . The slender nematodes peaked at L/W values between 25 and 33.

In July, 2 mo later, the small species were less abundant ( $4.5 \%$ of the total community) while Microlaimus marinus dominated $(14.8 \%)$, and the modal length clearly shifted towards larger-sized nematodes.

During all months, nematode length, width or L/W showed no trends with depth in the sediment (results not shown). In May, the vertical distribution of the dominant stout species (Epsilonema pustulatum, Metepsilonema comptum, Mannunema annulatum, Richtersia inaequalis, Tricoma sp. 1) showed no difference compared to the vertical distribution of the total nematode community (Fig. 5).

In order to understand the emergence of the stout and small species in May, the age/length structure of the assemblages (sediment slices and replicates pooled) is depicted in Fig. 6. Since both stout (L/W $<15$ ) and small (length $<700 \mu \mathrm{m}$ ) nematodes were virtually absent in March, the age structure for the entire community is shown. Comparing the age/length structure of stout and small nematodes (individuals identified as Epsilonema pustulatum, Metepsilonema comptum, Mannunema annulatum, Tricoma sp. 1, Richtersia inaequalis and all Rhynchonema species) with the slender nematodes in May and July reveals a lower proportion of juveniles in the lower size classes of the stout and small assemblage. In May, at least $50 \%$ of all stout and short species were adults, with lengths $>200 \mu \mathrm{m}$ (except 1 length class: $700 \mu \mathrm{m}$ ). In July, adults constituted $>60 \%$ of the stout and short nematodes with lengths $>300 \mu \mathrm{m}$. No obvious trends were observed for the slender assemblage throughout the sampling period. 

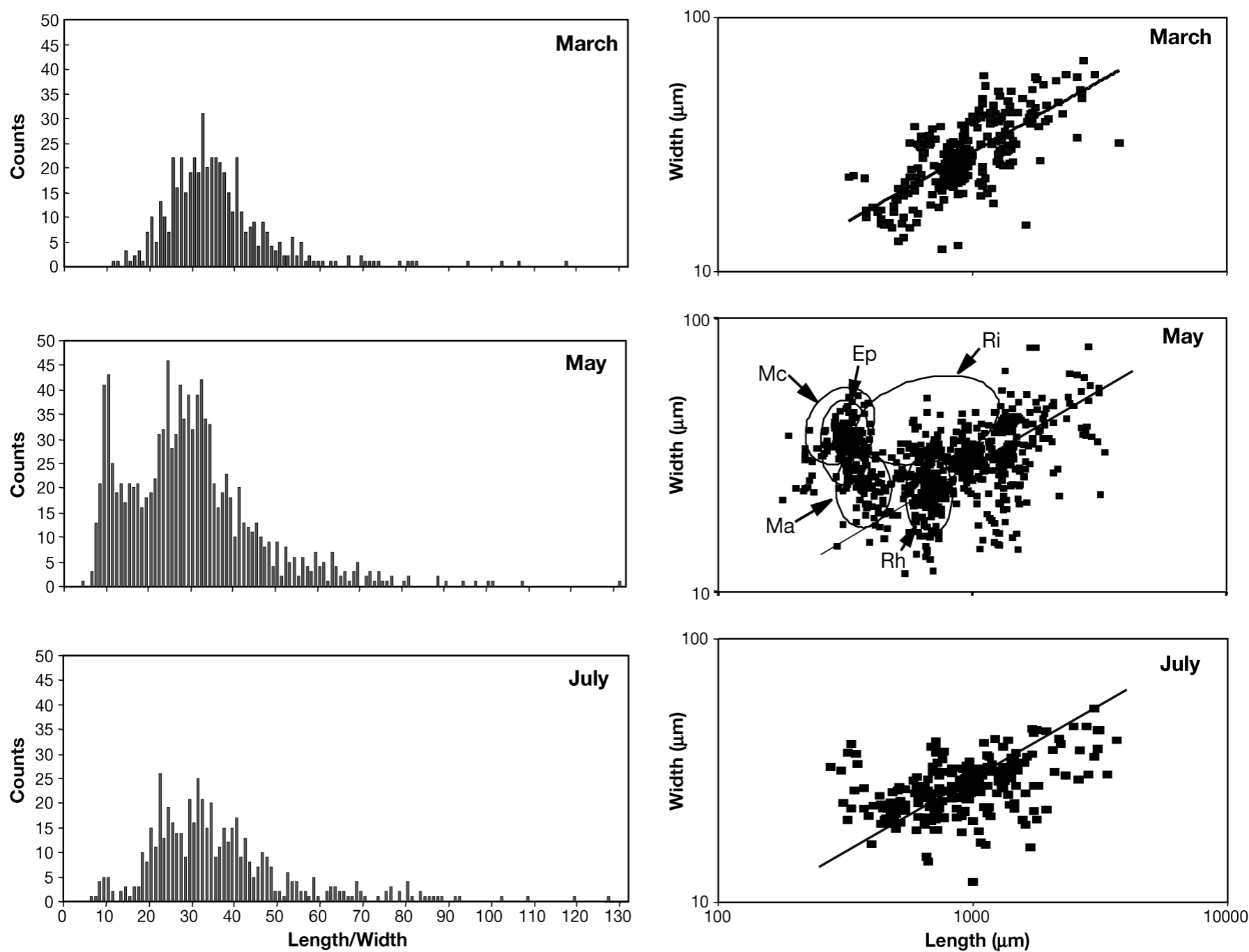

Fig. 3. Morphological diversity of North Sea nematodes before (March), during (May) and after (July) spring bloom deposition. Left hand graphs: length/width histograms; right hand graphs: body width versus body length (log scale). Ri: Richtersia inaequalis; Ep: Epsilonema pustulatum; Mc: Metepsilonema comptum; Ma: Manunema annulatum; Rh: Rhynchonema spp. All data per month combined

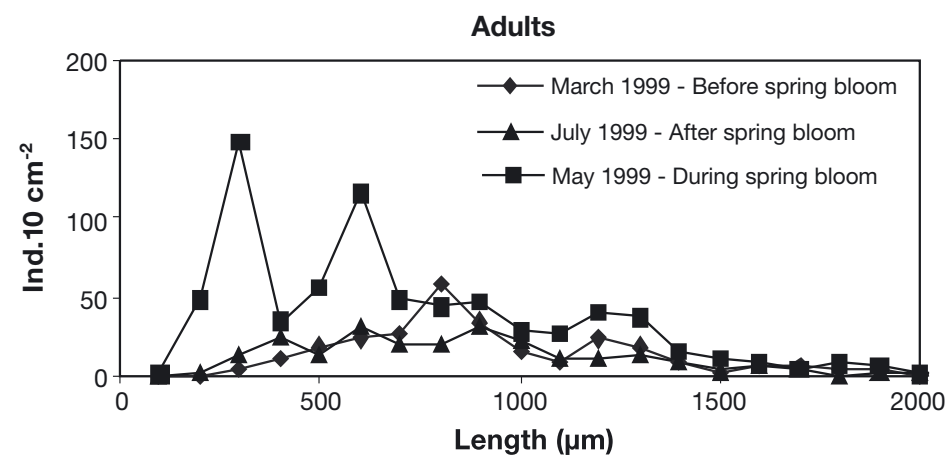

Fig. 4. Density versus length of adult nematodes before, during and after spring bloom sedimentation. Pooled data per sampling occasion

\section{DISCUSSION}

\section{Temporal patterns}

In coastal areas, a significant fraction of primary production may end up in the sediments, where it comprises food for benthic animals (Heip et al. 1995). At the study site, the phytoplankton population starts to grow in early March; algal densities peak at the end of April, after which the algal biomass declines rapidly (Rousseau 2000). As similar temporal patterns are observed for the chlorophyll in the supernatant water, at least part of the algal bloom settles on the sediment (Vanaverbeke et al. 2003).

Nematode densities, although generally low, varied almost 4 -fold over the 5 mo sampling period (Fig. 7). 


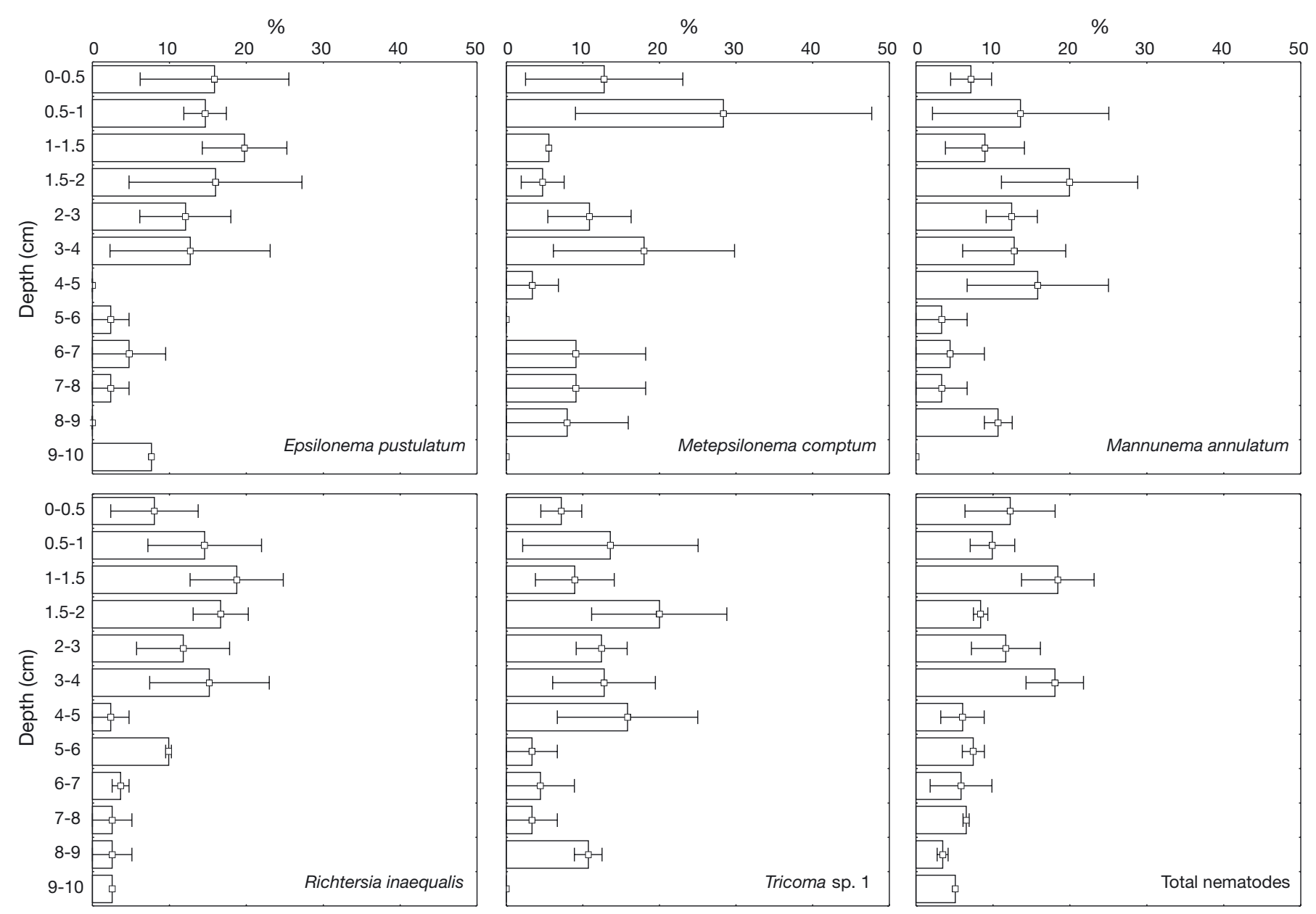

Fig. 5. Vertical distribution of dominant stout nematode species and total nematode community in May at Stn 330 . Relative abundances per sediment layer are mean of 3 replicates. Error bars $= \pm \mathrm{SE}$

Both small-scale spatial (order of $100 \mathrm{~m}$ ) and temporal effects (order of months) contributed to this variability, but the temporal signal explained most of the variation $\left(87 \%, F_{4,9}=15.1, \mathrm{p}=0.0005\right)$. Moreover, there was low variability in sediment composition between dates (median grain 330 to $360 \mu \mathrm{m}$ ) and a consistently positive redox layer over the analysed sediment depth $(<6 \mathrm{~cm})$.

The rapid increase in nematode densities from April onwards was largely attributable to the emergence of small species, for which adult lengths peaked at 300 to $400 \mu \mathrm{m}$ and at 600 to $700 \mu \mathrm{m}$. In May, more than $50 \%$ of the adult nematodes were smaller than $700 \mu \mathrm{m}$, whereas this was only $20 \%$ in March and $30 \%$ in July. One group of stout nematodes (defined with L/W ratios <15) was almost totally absent in March, but reached quite high densities (>130 individuals $10 \mathrm{~cm}^{-2}$ ) in May. In June, few members of this morphotype were present (17 individuals $10 \mathrm{~cm}^{-2}$ ) (Fig. 7).

Although our data do not allow us to make the distinction between birth and mortality rates, we can roughly assess the net rate of increase (which is the net effect of both) from March to May, and the net rate of decrease from May to June, by fitting an exponential growth model:

$$
\frac{\mathrm{d} N}{\mathrm{~d} t}=a N
$$

which can be solved as:

$$
N_{t}=N_{0} \mathrm{e}^{a t}
$$

where $N_{t}=$ nematode density at Time $t_{i} t=$ time in days, and $a=$ net increase $\mathrm{d}^{-1}$. The results indicated that stout nematodes $(\mathrm{L} / \mathrm{W}<15)$ increased their densities at a rate of $6.5 \% \mathrm{~d}^{-1}$ from March to May, approximately 4 times faster than the total community $\left(1.5 \% \mathrm{~d}^{-1}\right)$. Short species (length $<700 \mu \mathrm{m}$ ) increased in density at $3 \% \mathrm{~d}^{-1}$ over the same period. The same differences were observed when densities decreased from May to July, with a decline of $0.1 \% \mathrm{~d}^{-1}$ for the total community, $3.0 \% \mathrm{~d}^{-1}$ for stout nematodes and $1.7 \% \mathrm{~d}^{-1}$ for short adults. These data indicate that stout and short species are at an advantage when the bloom settles on the 


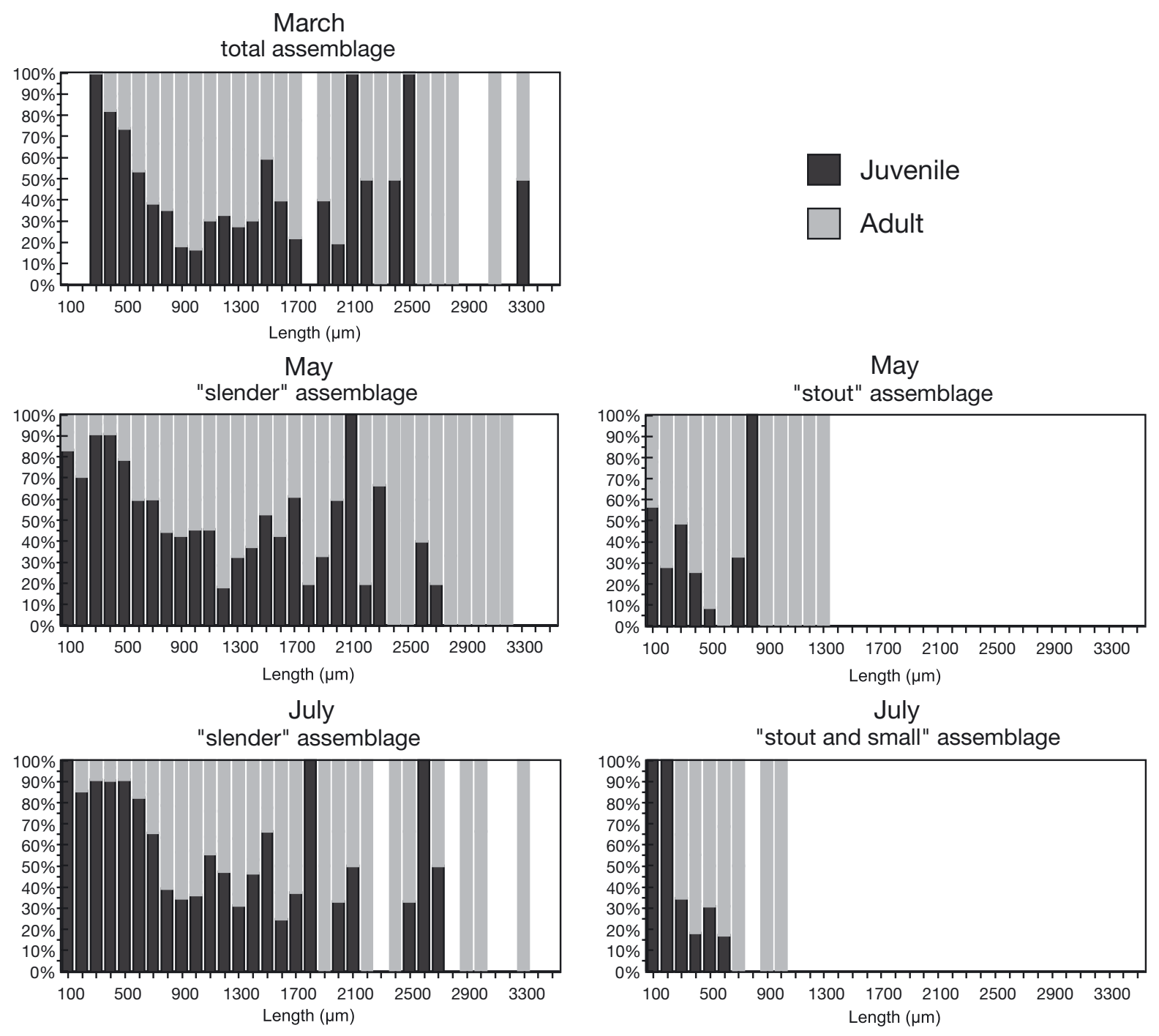

Fig. 6. Juvenile/adult distribution of slender and stout and small nematodes before, during and after spring bloom sedimentation. All data per month combined

sediment surface. Smaller species not only have higher growth rates (Peters 1983), and therefore reach adulthood faster, but they also have higher reproduction rates (Kooijman 1986). This is consistent with the higher rates of increase and the higher dominance of adults in the stout and short species (cf. the contribution of adults to total assemblages in Fig. 6). The small and stout species therefore have the ability to react opportunistically to a pulsed food supply. On the other hand, they also disappear at a much higher rate than the average nematode. Ammonia concentrations in the upper $4 \mathrm{~cm}$ of the sediment peaked in May and decreased again afterwards (Vanaverbeke 2003), suggesting that the organic material is remineralised quickly. Probably, the decrease in both stout and short nematodes can partly be attributed to food shortage. Being stout or small in-

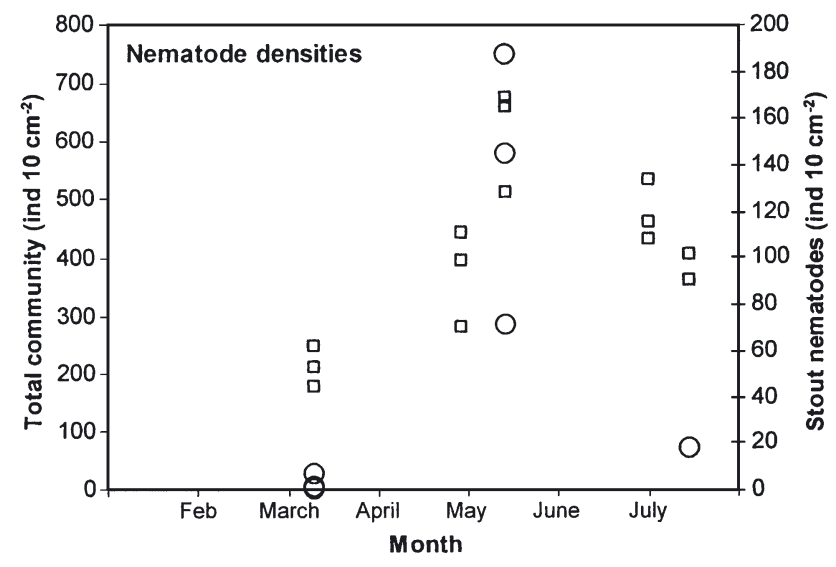

Fig. 7. Total (口) and stout (O) nematode densities each month at Stn 330. Each data point represents 1 replicate 
fers that the life span would be rather short (Kooijman 1986). Moreover, small species are more vulnerable to starvation than larger species (Kooijman 1986).

\section{Stout and small nematode assemblages}

Our results confirm the findings of Ratsimbazafy et al. (1994) and Soetaert et al. (2002) on the existence of different nematode morphotypes. Soetaert et al. (2002) explained the existence of the stout morphology as the result of evolutionary selection among distantly related taxa rather than resulting from phylogenetic lineage. Whereas on the Ligurian shelf and slope (Mediterranean Sea) the stout nematode assemblage consisted of desmoscolecids (Tricoma spp. 26\%, Desmoscolex spp. $24 \%$ ) and Richtersia spp. (30\%) (Soetaert et al. 2002), at our study site epsilonematids dominated the stout assemblage, followed by desmoscolecids and Mannunema annulatum. These belong to 3 different suborders within the Chromadorida. The predominance of the epsilonematids at our study site is probably due to the occurrence of sediments which are coarser than the deep-sea sediments of the stations used in the analysis of Soetaert et al. (2002). Members of the epsilonematids are usually found in sandy sediments, on sandbanks (Willems et al. 1982) and in open-sea sediments (Vincx 1986) where hydrodynamic forces can be substantial.

Soetaert et al. (2002) further hypothesised that stout nematode communities evolved as an adaptation to reduce predation pressure, as they combined large body width with armoured cuticulae. Similarly, the representatives of the stout nematodes at our site combined a stout shape with armour. The $\varepsilon$-like body shape of epsilonematids, together with the presence of long setae, make it difficult for a predator to swallow them, while Manunema annulatum has stout somatic setae on peduncles all over the body. The somewhat longer Rhynchonema species, which also show an opportunistic response to phytoplankton sedimentation, have similar cuticular ornamentation.

In deep-sea or continental slope stations, the L/W ratio of the nematodes showed consistent patterns with depth in the sediment, with stout nematodes always living in the upper layers of the sediment column. Soetaert et al. (2002) argued that their large width precluded them from inhabiting the suboxic and anoxic layers deeper in the sediment, since increasing body width decreases the capacity for oxygen uptake. The wider the body, the higher the oxygen diffusion limitations and the lower the tolerance of low oxygen levels. Our results corroborate this; in the absence of vertical oxygen-related gradients, no patterns in length, width or the length/width ratio were observed.
Our findings, however, contrast with the results of Soetaert et al. (2002) in 1 important aspect: whereas the existence of stout nematodes in the continental slope and deep-sea areas appears to be a persistent feature (they were found at all sites examined by Soetaert et al. 2002), their presence is clearly a transient phenomenon at our sampling site. Boon \& Duineveld (1998) and Boon et al. (1998) showed that, in North Sea sediments comparable with our sampling station, bacterial activity is very much related to the input of organic matter from the water column. It increases drastically after a food pulse and decreases again when the easily degradable fraction of the organic matter is broken down. Such pulses in bacterial activity are probably less pronounced along continental slopes and at deep-sea sites where nematodes have been studied, as the quality of organic material reaching the seafloor decreases with increasing water depth (Heip et al. 2001) and the reduced quality and availability of the organic matter, together with the lower temperatures, causes a prolonged remineralisation process (Soetaert et al. 1996). Except for the Richtersia species, the stout and short nematode species have very small buccal cavities, forcing them to feed selectively on small food items such as bacteria (Wieser 1953). Moens et al. (1999) demonstrated that even closely related nematode species show clear species-specific preferences for bacterial strains, bacterial densities and bacterial age. This might indicate that the preferential food source for this type of nematode at deep-sea sites is less pulsed than in coastal areas.

\section{CONCLUSIONS}

- At a sandy shelf site in the North Sea, the spring bloom opens a window of opportunity for small nematode species, whose densities rise vigorously immediately after the deposition of fresh organic matter. Within several months, their densities decline almost as quickly as they rose. This quick response can be explained by the life-history characteristics typical of these species.

- Many of these small nematodes are similar in shape to the 'stout nematode assemblage' described previously for ocean margin sites, with which, in addition, they share morphological similarities, in particular the presence of armour. However, being dominated by Epsilonematidae, the composition of the stout assemblage in the southern North Sea sediment differs from that at margin sites, where Desmoscolecidae are more prominent.

- Whereas in the southern North Sea sediment the presence of stout species seems a transient feature, in continental slope areas they seem to persist, possibly due to the continuous presence of suitable food items in these latter areas. 
Acknowledgements. We would like to thank the master and crew of the RVs 'Belgica', 'Zeehond' and 'Oostende XI' for their skilful help during the sampling. Many people from the Marine Biology Section gave a helping hand during the sampling period. Ann Vanreusel and Maaike Steyaert provided useful comments on earlier draft versions. Maarten Raes was responsible for the correct identification of Metepsilonema comptum. This research was funded by Ghent University (BOF, 19982003) and OSTC (Belgium Sustainable Development-North Sea Project MN/DD[40-41-42] and TROPHOS Contract No. EV/02/25A. This is publication no. 3314 from NIOO-CEME.

\section{LITERATURE CITED}

Boon AR, Duineveld GCA (1998) Chlorophyll a as a marker for bioturbation and carbon flux in southern and central North Sea sediments. Mar Ecol Prog Ser 162:33-43

Boon AR, Duineveld GCA, Berghuis EM, van der Weele JA (1998) Relationships between benthic activity and the annual phytopigment cycle in near-bottom water and sediments in the southern North Sea. Estuar Coast Shelf Sci 46:1-13

Buchanan JB (1984) Sediment analysis. In: Holme NA, McIntyre AD (eds) Methods for the study of marine benthos. Blackwell Scientific Publications, Oxford, p 41-65

Calder WA (1984) Size, function, and life history. Harvard University Press, Cambridge, MA

Graf G (1992) Benthic-pelagic coupling: a benthic view. Oceanogr Mar Biol Annu Rev 30:149-190

Heip C, Vincx M, Vranken G (1985) The ecology of free-living nematodes. Oceanogr Mar Biol Annu Rev 23:399-489

Heip CHR, Goosen NK, Herman PMJ, Kromkamp J, Middelburg JJ, Soetaert K (1995) Production and consumption of biological particles in temperate tidal estuaries. Oceanogr Mar Biol Annu Rev 33:1-149

Heip CHR, Duineveld G, Flach E, Graf G and 11 others (2001) The role of the benthic biota in sedimentary metabolism and sediment-water exchange processes in the Goban Spur area (NE Atlantic). Deep-Sea Res II 48:3223-3243

Kooijman SALM (1986) Energy budgets can explain body size relations. J Theor Biol 121:269-282

Mantoura RFC, Llewellyn CA (1983) The rapid determination of algal chlorophyll and cartenoid pigments and their breakdown products in natural waters by reverse-phase high-performance liquid chromatography. Anal Chim Acta 151:297-314

Editorial responsibility: Lisa Levin (Contributing Editor), La Jolla, California, USA
Moens T, Verbeeck L, de Maeyer A, Swings J, Vincx M (1999) Selective attraction of marine bacterivorous nematodes to their bacterial food. Mar Ecol Prog Ser 176:165-178

Peters RH (1983) The ecological implications of body size. Cambridge University Press, Cambridge

Ratsimbazafy R, Boucher G, Dauvin JC (1994) Mesures indirectes de la biomasse des nématodes du meiobenthos subtidal de la Manche. Cah Biol Mar 35:511-523

Rex MA, Etter RJ (1998) Bathymetric patterns of body size: implications for deep-sea biodiversity. Deep-Sea Res 45: 103-127

Rousseau V (2000) Dynamics of Phaeocystis and diatom blooms in the eutrophicated coastal waters of the southern Bight of the North Sea. PhD thesis, Université Libre de Bruxelles, Brussels

Schwinghamer P (1983) Generating ecological hypothesis from biomass spectra using causal analysis: a benthic example. Mar Ecol Prog Ser 13:151-166

Sebens KP (1987) The ecology of indeterminate growth in animals. Annu Rev Ecol Syst 18:371-407

Soetaert K, Herman PMJ, Middelburg JJ (1996) Dynamic response of deep-sea sediments to seasonal variations: a model. Limnol Oceanogr 41:1651-1668

Soetaert K, Muthumbi A, Heip C (2002) Size and shape of ocean margins nematodes: morphological diversity and depth-related patterns. Mar Ecol Prog Ser 242:179-193

Tita G, Vincx M, Desrosier G (1999) Size spectra, body width and morphotypes of intertidal nematodes: an ecological interpretation. J Mar Biol Assoc UK 79:1007-1015

Vanaverbeke J (2003) Structural and functional diversity of the meiobenthos on the Belgian Continental Shelf, with emphasis on nematode communities. PhD thesis, Ghent University, Gent

Vanaverbeke J, Steyaert M, Vanreusel A, Vincx M (2003) Nematode biomass spectra as descriptors of functional changes due to human and natural impact. Mar Ecol Prog Ser 249:157-170

Vincx M (1986) Free-living marine nematodes from the Southern Bight of the North Sea. PhD thesis, Ghent University, Gent

Wieser W (1953) Die Beziehung zwischen Mundhöhlengestalt, Ernährungsweise und Vorkommen bei freilebenden marinen Nematoden. Ark Zool 2:439-484

Willems K, Vincx M, Claeys D, Vanosmael C, Heip C (1982) Meiobenthos of a sublittoral sandbank in the Southern Bight of the North Sea. J Mar Biol Assoc UK 62: $535-548$

Submitted: June 2, 2003; Accepted: February 20, 2004 Proofs received from author(s): June 1, 2004 